\title{
Partial and full dehydration impact on germination of 4 warm-season grasses
}

\author{
WULIAM E. EMMERICH AND STUART P. HARDEGREE
}

\begin{abstract}
Authors are soil scientist, USDA-ARS, Southwest Watershed Research Center, 2000 E. Allen Rd., Tucson, Ariz, 85719 and plant physiologist, USDA-ARS Northwest Watershed Research Center, 800 Park Blvd., Plaza IV, Suite 105, Baise, Ida. 83712 .
\end{abstract}

\begin{abstract}
Precipitation patterns in the arid southwest U.S. can be highly variable during the summer monsoon season. The ability of germinating seeds to withstand temporary periods of dehydration may determine their potential for successful regeneration under present and future climatic regimes. Germination with short-term hydration and dehydration sequences was compared to constant water potential germination for sideoats grama [Bouteloua curtipendula (Michaux) Torrey], buffelgrass [Cenchrus ciliaris L.], Lehmann lovegrass [Eragrostis lehmanniana Nees], and kleingrass [Panicum coloratum L.]. Seeds were imbibed at $-0.2 \mathrm{MPa}$ for 1 to 4 days, then either air dried or partially dehydrated at $-3.0 \mathrm{MPa}$ for 1 to 4 days before being returned to the initial imbibition solution for a total 14-day incubation-dehydration period. One day of imbibition at $-0.2 \mathrm{MPa}$ advanced germination to a stage that resulted in significant reductions $(\mathbf{P}<0.05)$ in total germination from subsequent dehydration. The significant reductions still allowed $>48 \%$ of the viable seeds to germinate after dehydration. Longer imbibition times also exhibited significant reductions in germination for buffelgrass and kleingrass. For kleingrass airdried dehydration compared to $-\mathbf{3 . 0} \mathrm{MPa}$ produced significant reductions $(P<0.05)$ in germination with $2-3$ days imbibition. The length of the dehydration periods produced significant differences $(P<0.05)$ in total germination for Lehmann lovegrass and kleingrass. Partial dehydration significantly increased germination rate for sideoats grama, buffelgrass, and kleingrass, while airdried dehydration significantly reduced buffelgrass germination rate. Any dehydration during germination was detrimental and >1-day imbibition followed by dehydration seemed the critical time upon which a dramatic reduction in germination occurs.
\end{abstract}

Key Words: sideoats grama, buffelgrass, lehmann lovegrass, kleingrass, imbibition, germination enhancement

The timing and duration of seedbed moisture can be highly variable, in southern Arizona with a summer monsoon climatic regime (Cox and Jordan 1983, Osborn 1968). Hydration and dehydration sequences can affect subsequent seed germination. Seeds imbibed to subgermination levels without radicle extension (Haferkamp et al. 1977b, Hardegree and Emmerich 1992a,

Authors wish to thank Dr. Gary Richardson for assistance in statistical analyses. Manuscript accepted 8 Sep 95. 1992b) and seeds imbibed and air-dried before radicle extension occurs (Bleak and Keller 1974, Burgass and Powell 1984) may germinate more rapidly with subsequent rainfall events. Duration and magnitude of hydration and dehydration regimes can be critical to the germination process (Lalonde and Bewley 1985, Watt 1982). Although, dehydration before the early stages of radicle extension may enhance future germination (Wilson 1973, Burgass and Powell 1984), dehydration at later stages in the germination process may reduce seed viability (Lalonde and Bewley 1985, Hegarty 1978). Information as to the effect of various wetting and drying sequences on germination has been used to optimize planting dates for range grasses (Frasier and Lopez 1990, Frasier et al. 1984, 1985). The purpose of this study was to determine the effects of short-term hydration and dehydration sequences on germination response of 4 grasses, compare the response to constant water potential germination, and the potential implications to seedling establishment. Specific objectives were to evaluate the critical time requirements for initial radicle extension and potential for germination enhancement of seeds that are partially or fully dehydrated after an initial imbibition period.

\section{Materials and Methods}

Sideoats grama [Bouteloua curtipendula (Michaux) Torrey], buffelgrass [Cenchrus ciliaris L.], Lehmann lovegrass [Eragrostis lehmanniana Nees], and kleingrass [Panicum coloratum $\mathrm{L}$.] seeds were selected to evaluate short-term hydration and dehydration on germination. These species were chosen because they are widely used for revegetation in the southwestern United States (Cox et al. 1987) and because information already exists as to their germination response to a number of environmental variables (Hardegree and Emmerich 1990a, 1991, 1992a, 1992b, Emmerich and Hardegree 1990, 1991, Wester 1991).

The Lehmann lovegrass seeds required seed coat disruption to remove dormancy (Wright 1973, Haferkamp et al. 1977a, 1977b). Therefore, seeds were mechanically scarified following the procedure described by Wright (1973) with 0.5 -ml seed samples and an 8-second scarification interval.

Seed germination was conducted in a water potential control system consisting of $50 \mathrm{~mm}$ diameter by $85 \mathrm{~mm}$ high clear plastic snap-top germination vials with a germination cup inside 
(Hardegree and Emmerich 1992a). Germination cups, fitted with Whatman ${ }^{1}$ No. 42 filter paper bottoms instead of cellulose membrane, were supported inside the vials in contact with about $65 \mathrm{ml}$ of polyethylene glycol solution $(8,000 \mathrm{MW}$ ) (Union Carbide, Danbury, Conn. ${ }^{1}$ ) or deionized water. In this application, seeds were allowed to come into direct contact with the osmotic solution used to control water potential. Seed contact with polyethylene glycol solution does not have detrimental effects on germination of these species beyond those induced by a reduction in water potential (Emmerich and Hardegree 1990, Hardegree and Emmerich 1994).

Polyethylene glycol was mixed with deionized water to yield osmotic water potentials of -0.2 and $-3.0 \mathrm{MPa}$ (Hardegree and Emmerich 1990b, Emmerich and Hardegree 1991). A -0.2-MPa water potential compared to $0 \mathrm{MPa}$ elicits near maximum germination response for 3 of the test species (Hardegree and Emmerich 1990a) and was felt to represent moist soil conditions. The -3.0 MPa treatment is a subgermination water potential that can occur in dry soils. Replicate samples of 35 seeds of each species were initially imbibed for either $1,2,3$, or 4 days in contact with a $-0.2-\mathrm{MPa}$ solution. One-half of the germination cups were removed from the vials after the initial equilibration time, blotted dry of polyethylene glycol solution, placed next to the vial, and air dried for $1,2,3$, or 4 days. The germination cups that were blotted dry for the air-dry dehydration took about 3 hours to reach air dryness in $40-50 \%$ relative humidity. The other onehalf of the germination cups was switched to an adjacent vial containing polyethylene glycol solution at $-3.0 \mathrm{MPa}$ to partially dehydrate for $1,2,3$, or 4 days. After air drying or partial dehydration periods, all germination cups were returned to the original vials containing -0.2-MPa solution for rehydration. All combinations of species, initial equilibration period, and dehydration sequence were replicated 6 times. Vials were in a randomized complete block design inside a temperature controlled room at $25 \pm 1^{\circ} \mathrm{C}$ under both fluorescent and incandescent light for 12 hours per day. Included in each block were control seeds from each species that were germinated at the same time in contact with -0.2-MPa solution and not subjected to a dehydration period.

Fungal growth was restricted by treating seeds with a $50 \mu \mathrm{l}$ Daconil (tetrachloroisophthalonitrile) suspension (2.5 $100 \mathrm{ml}^{-1}$ ) at the beginning of the study. Seeds were examined daily and those exhibiting radicle extension of $\geq 2 \mathrm{~mm}$ were considered germinated, counted and removed. Seeds that developed fungal growth were removed and termed nonviable. The test was terminated 14 days from the start of the initial equilibration period.

Three germination indices were calculated: 1.) total 14-day percent germination; 2.) total percent germination for seeds that germinated after the dehydration periods; and 3 .) days to $25 \%$ germination starting at the completion of the dehydration treatments and based on the number of seeds germinating after the dehydration treatment. Days to $25 \%$ germination was calculated by linear interpolation between data points. Treatments with low total germination after the dehydration periods exhibited high variability in germination rate as only a few seeds would be used to characterize treatment response. Therefore a value of $>20 \%$ of the seed germinating after dehydration was used as a minimum value to calculate days to $25 \%$ germination starting after dehydration.

\footnotetext{
Mention of trade names or proprietary products does not indicate endorsement by USDA, and does not imply its approval to the exclusion of other products that may also be suitable.
}

Ninety-five percent confidence intervals were calculated and used to test for significant treatment differences. Treatments were considered to be significantly different if there was no confidence interval overlap. This is a more conservative test for significance than was utilized in similar studies, where overlap of confidence interval and predicted mean was used (Hardegree and Emmerich 1990a; Hardegree and Emmerich 1992a). The control seeds could not be included in an analysis of variance as they were not subjected to any of the main effects. An analysis of variance without the control was not performed to determine significant interactions of main effects as they can be evaluated by data presented in the tables.

\section{Results}

\section{Sideoats Grama}

Sideoats grama seed germinated so rapidly that near maximal germination occurred by the second day of imbibition at -0.2 MPa (Fig. 1). Because of the rapid response, germination was

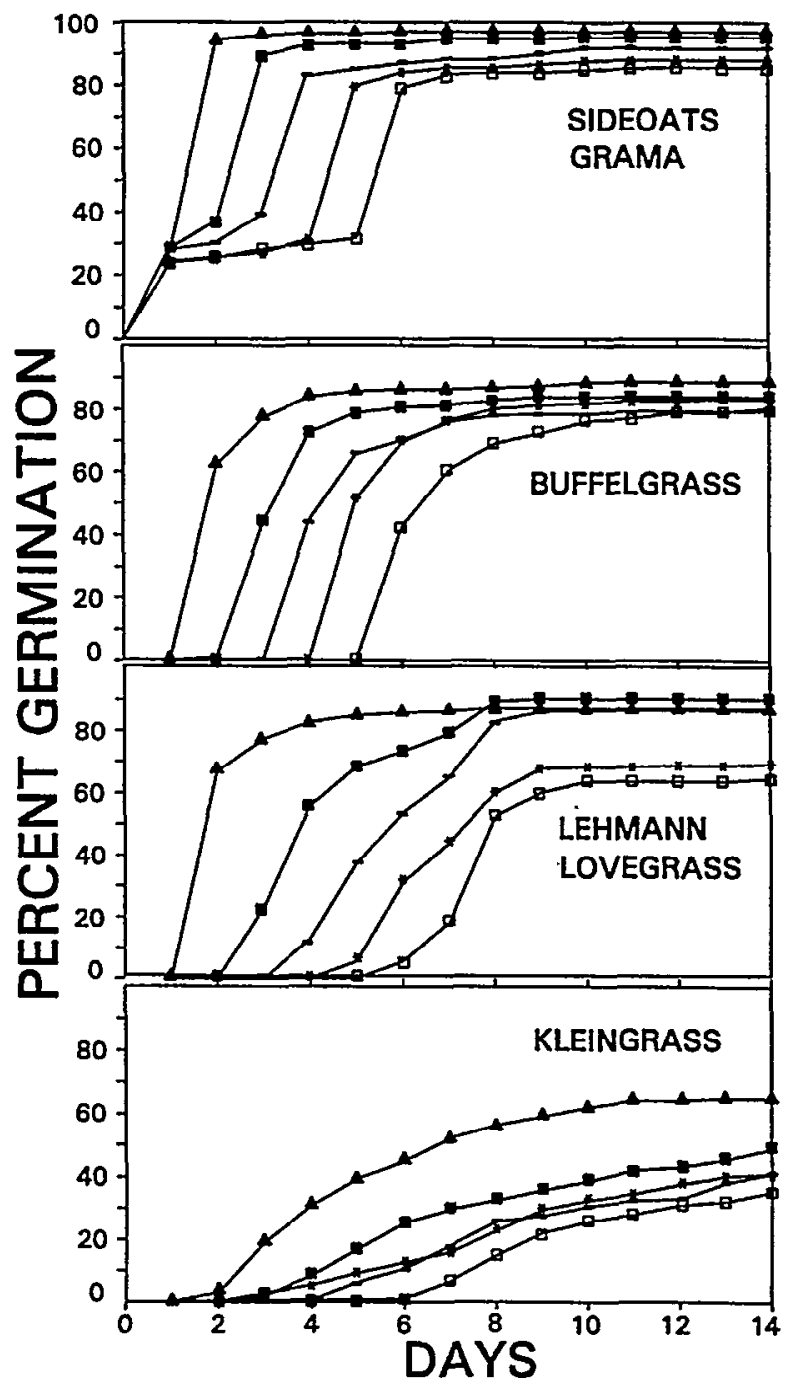

Fig. 1. Percent germination vs time for sideoats grama, buffelgrass, Lehmann lovegrass, and kleingrass exposed to 1 day $-0.2 \mathrm{MPa}$ imbibition and partial dehydration at $-3.0 \mathrm{MPa}$ for 1 day (-R-), 2 day (-), 3 day $\left(-^{*}\right), 4$ day (--) and rehydration at $-0.2 \mathrm{MPa}$, plus germination at constant $-0.2 \mathrm{MPa}\left(-\Lambda_{-}\right)$. 
affected only by dehydration events that started 1 day after initiation of imbibition. Air-dry dehydration and 1-day imbibition significantly reduced total germination to $16-19 \%$ less than controls (Table 1), but germination was unaffected by the length of the dehydration period. Partial dehydration of sideoats grama seed after 1 day of imbibition reduced germination less than air-dry dehydration. Partial dehydration for 1 day reduced germination only $3 \%$ but with 4 days of dehydration this increased to $11 \%$ less than controls.

Fifty-four to $67 \%$ of the sideoats grama seeds germinated after partial and full dehydration with 1 day imbibition (Table 2). Airdry seeds germinated slightly less than partially dehydrated seeds and the length of dehydration did not influence germination. Germination after longer imbibition times was minimal, because most seed had germinated before dehydration was initiated.

Sideoats grama seeds that survived dehydration after 1 day of imbibition had the most rapid germination rate of all species (Table 3). The increase in germination rate compared to controls for air-dry dehydration was small, while partially dehydrated seeds had significant increases. Dehydration period length did not influence the germination rate.

\section{Buffelgrass}

Buffelgrass seeds germinated slower than sideoats grama and were affected by dehydration initiated with $>1$ day of imbibition (Fig. 1). Total germination of buffelgrass was significantly reduced for most dehydration periods with 1 to 3 days imbibition (Table 1). The reductions in germination were up to $24 \%$ compared to the control. Partial dehydration reduced germination of buffelgrass less than air-dry dehydration. There was a trend of reduced germination with increasing length of air-dry dehydration with 1 day imbibition.

At least $65 \%$ of the buffelgrass seed germinated after dehydration with 1 day imbibition and was equal to total germination (Table 1 and 2). Germination after dehydration with longer imbibition times was much lower. Germination after dehydration was always higher with partial than air-dry dehydration.

Buffelgrass seeds that were air dried after 1 day imbibition germinated significantly slower than control seeds, except for 4 day dehydration (Table 3). Low germination prevented a rate determination with a 2 day imbibition followed by air-dry dehydration. In contrast buffelgrass seeds imbibed for 1 day followed by partial dehydration had significant increases in germination rate compared to controls. Longer imbibition times produced nonsignificant increases in germination rates.

Table 1. Mean 14 day percent germination ( $\pm 95 \%$ confidence intervals) at constant water potential, and after 1-4 days initial imbibition followed by $1-$ 4 days partial or full dehydration.

\begin{tabular}{|c|c|c|c|c|c|c|c|c|}
\hline \multirow{3}{*}{$\begin{array}{c}\text { Days of Constant } \\
\text { Dehydration }-0.2 \mathrm{MPa} \\
\text { Water }\end{array}$} & \multicolumn{8}{|c|}{ Initial imbibition days at $-0.2 \mathrm{MPa}^{\mathrm{T}}$} \\
\hline & \multicolumn{2}{|c|}{1} & \multicolumn{2}{|c|}{2} & \multicolumn{2}{|c|}{3} & \multicolumn{2}{|c|}{4} \\
\hline & air & -3.0 & air & -3.0 & air & -3.0 & air & -3.0 \\
\hline Potential & dry & $\mathrm{MPa}$ & dry & $\mathrm{MPa}$ & dry & $\mathrm{MPa}$ & dry & $\mathrm{MPa}$ \\
\hline
\end{tabular}

Sideoats grama

$98 \pm 4$

$\begin{array}{lll}81 \pm 10^{* 2} & 95 \pm 5 & 95 \pm 4 \\ 82 \pm 12^{*} & 92 \pm 6 & 93 \pm 5 \\ 81 \pm 9 * & 88 \pm 1^{*} & 96 \pm 3 \\ 79 \pm 12^{*} & 87 \pm 7^{*} & 92 \pm 4\end{array}$

$89 \pm 4$

$\begin{array}{lll}81 \pm 8 & 84 \pm 11 & 62 \pm 13^{*} \\ 72 \pm 7^{*} & 79 \pm 5^{*} & 76 \pm 4^{*} \\ 73 \pm 13^{*} & 83 \pm 46 & 68 \pm 14^{*} \\ 65 \pm 14^{*} & 81 \pm 4^{*} & 66 \pm 9^{*}\end{array}$

\begin{tabular}{ll}
$97 \pm 3$ & $97 \pm 3$ \\
$93 \pm 8$ & $96 \pm 5$ \\
$96 \pm 2$ & $97 \pm 4$ \\
$96 \pm 6$ & $95 \pm 5$ \\
\multicolumn{2}{c}{ Buffelgrass }
\end{tabular}

$\begin{array}{lll}98 \pm 1 & 96 \pm 2 & 98 \pm 3 \\ 95 \pm 3 & 96 \pm 6 & 95 \pm 6 \\ 93 \pm 3 & 97 \pm 4 & 97 \pm 3 \\ 96 \pm 3 & 97 \pm 4 & 98 \pm 3\end{array}$

$87 \pm 7$

$\begin{array}{lll}85 \pm 6 & 90 \pm 5 & 74 \pm 8 \\ 68 \pm 21 & 87 \pm 8 & 76 \pm 7 \\ 66 \pm 22 & 69 \pm 17 & 75 \pm 6 \\ 52 \pm 20^{*} & 65 \pm 16 & 74 \pm 7\end{array}$

$65 \pm 10$

$0 \quad 65 \pm 10$

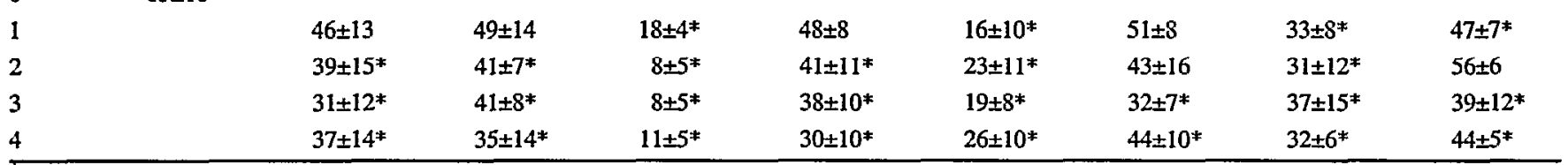

After 1-4 days at initial imbibition water potential switched to air dry or $-3.0 \mathrm{MPa}$ dehydration for $1-4$ days then rehydration for a total 14 days.

2 Values with a * were considered significantly different $(\mathrm{P}<0.05)$ from the constant $-0.2-\mathrm{MPa}$ water potential by non-overlap of confidence intervals. 


\section{Lehmann lovegrass}

Lehmann lovegrass germination response to dehydration was similar to that exhibited by buffelgrass (Table 1). Germination reductions were up to $35 \%$ with 1 day imbibition followed by airdry dehydration, while partial dehydration reductions were up to $22 \%$. The absence of significant germination reductions was attributed to the large variability in Lehmann lovegrass germination as measured by the confidence intervals. Germination with 1 day imbibition was significantly reduced at 4 days of dehydration compared to 1 day.

Lehmann lovegrass seed germination after dehydration with 1 day imbibition was at least $52 \%$ and accounted for the total germination (Table 1 and 2). With longer imbibition times few seeds germinated after the dehydration treatments. Germination after dehydration for all imbibition times was lower in the air-dry than partial dehydration treatments.

Germination rate for Lehmann lovegrass seeds was unaffected by dehydration treatments (Table 3 ). Lehmann lovegrass was the only species not to have a germination rate response to dehydration.

\section{Kleingrass}

Kleingrass seed germination was much slower than the other species (Fig. 1). With slower germination kleingrass seeds were susceptible to dehydration effects after all imbibition periods. Germination was significantly reduced for a majority of the dehydration treatments with up to $57 \%$ reduction (Table 1). Increasing length of dehydration period with 1 day of imbibition tended to reduce germination similar to buffelgrass and Lehmann love- grass. Kleingrass germination for air-dry compared to partial dehydration treatments was the only species to have significantly less germination for any of the imbibition periods.

Kleingrass seed germination after dehydration with 1 day imbibition was at least $31 \%$ (Table 2). Germination after dehydration with 1-2 days imbibition was close to total germination (Table 1 and 2). Germination after dehydration for longer imbibition times and air-dry dehydration germination was poor, while for partial dehydration it was much greater than the other species.

Germination rate of kleingrass seeds with 1 day imbibition followed by dehydration was not different than controls (Table 3 ). Slower germination and the less detrimental effect of partial dehydration on germination allowed for germination rate calculations through the 3 day imbibition period. At 2-3 days imbibition and for partial dehydration, germination rate was significantly increased for many of the dehydration periods.

\section{Discussion}

The reductions in total germination, relative to the controls, represents seeds in the germination process that are subsequently damaged by dehydration treatments. Loss of viability in seeds at an advanced stage of germination is usually attributed to cellular damage in growing root tissue caused by dehydration (Hegarty 1978). The overall influence of dehydration intensity on germination for the species can be seen in Figures 1 and 2, with less damage from partial dehydration. Seed germination was essentially completed by the third day except for kleingrass, therefore germi-

Table 2. Mean percent germination ( $₫ 95 \%$ confidence intervals) that occurred after dehydration treatments.

\begin{tabular}{|c|c|c|c|c|c|c|c|c|}
\hline Days & & & & itial in & days a & & & \\
\hline Dehydration & & & & & & & & \\
\hline & $\begin{array}{l}\text { air } \\
\text { dry }\end{array}$ & $\begin{array}{l}-3.0 \\
\mathrm{MPa}\end{array}$ & $\begin{array}{l}\text { air } \\
\text { dry }\end{array}$ & $\begin{array}{l}-3.0 \\
\text { Mpa }\end{array}$ & $\begin{array}{l}\text { air } \\
\text { dry }\end{array}$ & $\begin{array}{l}-3.0 \\
\mathrm{MPa}\end{array}$ & $\begin{array}{l}\text { air } \\
\text { dry }\end{array}$ & $\begin{array}{l}-3.0 \\
\mathrm{MPa}\end{array}$ \\
\hline
\end{tabular}

\begin{tabular}{|c|c|c|c|c|c|c|c|c|}
\hline \multicolumn{9}{|c|}{ Sideoats grama } \\
\hline 1 & $59 \pm 16$ & $67 \pm 5$ & $1 \pm 9$ & $3 \pm 5$ & $0 \pm 4$ & $1 \pm 3$ & $0 \pm 3$ & $1 \pm 4$ \\
\hline 2 & $58 \pm 18$ & $64 \pm 13$ & $1 \pm 8$ & $4 \pm 12$ & $0 \pm 8$ & $1 \pm 5$ & $0 \pm 9$ & $1 \pm 8$ \\
\hline 3 & $58 \pm 14$ & $64 \pm 10$ & $1 \pm 5$ & $3 \pm 5$ & $0 \pm 5$ & $1 \pm 10$ & $0 \pm 6$ & $0 \pm 4$ \\
\hline 4 & $54 \pm 18$ & $62 \pm 10$ & $2 \pm 6$ & $3 \pm 9$ & $0 \pm 7$ & $1 \pm 6$ & $0 \pm 5$ & $0 \pm 4$ \\
\hline \multicolumn{9}{|c|}{ Buffelgrass } \\
\hline 1 & $81 \pm 8$ & $84 \pm 11$ & $3 \pm 19$ & $27 \pm 22$ & $1 \pm 12$ & $7 \pm 14$ & $1 \pm 10$ & $4 \pm 10$ \\
\hline 2 & $72 \pm 7$ & $79 \pm 5$ & $9 \pm 12$ & $30 \pm 16$ & $1 \pm 15$ & $11 \pm 17$ & $2 \pm 12$ & $2 \pm 9$ \\
\hline 3 & $73 \pm 13$ & $83 \pm 4$ & $5 \pm 22$ & $30 \pm 17$ & $2 \pm 19$ & $9 \pm 13$ & $0 \pm 8$ & $2 \pm 13$ \\
\hline 4 & $65 \pm 14$ & $81 \pm 4$ & $8 \pm 11$ & $20 \pm 15$ & $1 \pm 7$ & $4 \pm 14$ & $0 \pm 10$ & $0 \pm 3$ \\
\hline \multicolumn{9}{|c|}{ Lehmann lovegrass } \\
\hline 1 & $85 \pm 6$ & $90 \pm 5$ & $5 \pm 11$ & $26 \pm 14$ & $3 \pm 8$ & $10 \pm 11$ & $1 \pm 6$ & $4 \pm 7$ \\
\hline 2 & $68 \pm 21$ & $87 \pm 8$ & $4 \pm 11$ & $23 \pm 6$ & $2 \pm 15$ & $7 \pm 5$ & $1 \pm 8$ & $5 \pm 6$ \\
\hline 3 & $66 \pm 22$ & $69 \pm 17$ & $6 \pm 9$ & $20 \pm 15$ & $4 \pm 17$ & $7 \pm 11$ & $2 \pm 10$ & $3 \pm 7$ \\
\hline 4 & $52 \pm 20$ & $65 \pm 16$ & $5 \pm 10$ & $18 \pm 17$ & $2 \pm 6$ & $9 \pm 11$ & $1 \pm 8$ & $3 \pm 11$ \\
\hline \multicolumn{9}{|c|}{ Kleingrass } \\
\hline 1 & $46 \pm 13$ & $49 \pm 14$ & $14 \pm 54$ & $44 \pm 11$ & $1 \pm 13$ & $26 \pm 11$ & $2 \pm 12$ & $17 \pm 12$ \\
\hline 2 & $39 \pm 15$ & $41 \pm 7$ & $7 \pm 5$ & $39 \pm 11$ & $1 \pm 16$ & $24 \pm 24$ & $1 \pm 16$ & $16 \pm 7$ \\
\hline 3 & $31 \pm 12$ & $41 \pm 8$ & $5 \pm 6$ & $37 \pm 10$ & $2 \pm 10$ & $15 \pm 12$ & $1 \pm 20$ & $14 \pm 18$ \\
\hline 4 & $37 \pm 14$ & $35 \pm 14$ & $8 \pm 8$ & $28 \pm 12$ & $2 \pm 13$ & $21 \pm 16$ & $4 \pm 8$ & $10 \pm 13$ \\
\hline
\end{tabular}

After $1-4$ days at initial imbibition water potential switched to air-dry or $-3.0-\mathrm{MPa}$ dehydration for $1-4$ days then rehydration. 


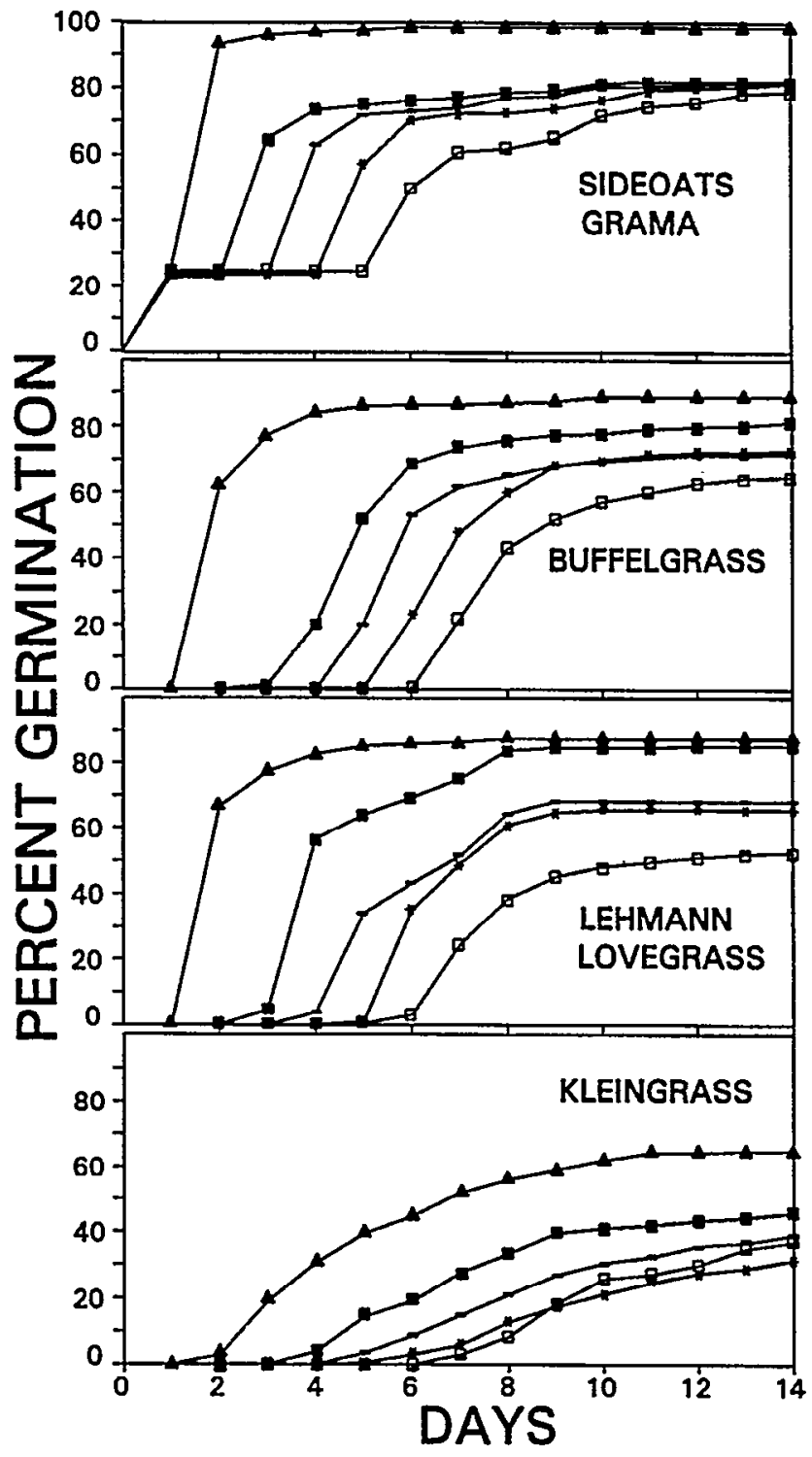

Fig. 2. Percent germination vs time for sideoats grama, buffelgrass, Lehmann lovegrass, and kleingrass exposed to 1 day $-0.2 \mathrm{MPa}$ imbibition and air-dry dehydration for 1 day $(-2), 2$ day $(-), 3$ day (-*), 4 day (--) and rehydration at $-0.2 \mathrm{MPa}$, plus germination at constant $-0.2 \mathrm{MPa}(-\Lambda-)$.

nation was affected only by dehydration after 1-2 days imbibition. Seedling establishment of germinating seeds would then be dependent on root extension into the soil as surface soil moisture is depleted. Frasier et al. $(1984,1985)$ showed high mortality rates for seedlings subjected to dehydration soon after germination. Sideoats grama, the fastest germinating species, had completed $24 \%$ germination after only 1 day of imbibition. This species also has a rapid root elongation rate (Simanton and Jordan 1986), yet its fast growth rate may not be adequate to obtain deeper soil moisture in rapidly drying coarse soils (Roundy et al. 1993).

A precipitation event that produces one day of soil moisture would not germinate all viable seeds, even for the fast germinating sideoats grama. For all species at least $48 \%$ of viable seeds were able to germinate after 1 day imbibition followed by dehydration

Table 3. Mean days to $25 \%$ germination ( $\pm 95 \%$ confidence intervals) starting after dehydration for seeds that survived 1 day initial imbibition and 1 to 4 day dehydration treatment, and for seeds that germinated at constant $-0.2 \mathrm{MPa}$ water potential.

\begin{tabular}{lcccc}
\hline \hline Days & \multicolumn{4}{c}{ Dehydration treatment after 1 day imbibition } \\
\cline { 2 - 5 } Dehydration & air & -3.0 & air & -3.0 \\
& dry & $\mathrm{MPa}$ & dry & $\mathrm{MPa}$ \\
\hline
\end{tabular}

(Days)

Constant

Water

Potential

1

2

3

4

\section{Constant}

Water

1

2

3

4
Sideoats grama

$0.65 \pm 0.14$
Buffelgrass

$1.4 \pm 0.1$
Potential

\begin{tabular}{|c|c|c|c|}
\hline $0.38 \pm 0.15$ & $0.28 \pm 0.02^{*^{2}}$ & $2.0 \pm 0.3^{*}$ & $0.5 \pm 0.1^{*}$ \\
\hline $0.42 \pm 0.19$ & $0.30 \pm 0.01^{*}$ & $1.9 \pm 0.3^{*}$ & $0.5 \pm 0.1^{*}$ \\
\hline $0.45 \pm 0.14$ & $0.29 \pm 0.03^{*}$ & $1.9 \pm 0.2^{*}$ & $0.4 \pm 0.1^{*}$ \\
\hline $0.45 \pm 0.13$ & $0.28 \pm 0.02^{*}$ & $1.8 \pm 0.3$ & $0.5 \pm 0.1^{*}$ \\
\hline \multicolumn{2}{|c|}{$\frac{\text { Lehmann lovegrass }}{1.3 \pm 0.1}$} & \multicolumn{2}{|c|}{$\frac{\text { Kleingrass }}{3.0 \pm 0.5}$} \\
\hline
\end{tabular}

$\begin{array}{llll}1.3 \pm 0.2 & 1.0 \pm 0.4 & 3.1 \pm 0.9 & 2.4 \pm 0.5 \\ 1.6 \pm 0.3 & 1.4 \pm 0.3 & 3.4 \pm 1.3 & 3.0 \pm 1.0 \\ 1.6 \pm 0.4 & 1.7 \pm 0.5 & 2.9 \pm 1.1 & 2.0 \pm 1.0 \\ 1.8 \pm 0.7 & 1.8 \pm 0.5 & 3.1 \pm 0.6 & 2.2 \pm 0.7\end{array}$
dehydration for $1-4$ days then rehydration.

${ }^{2}$ Values with $\mathrm{a}$ * were considered significantly different $(\mathrm{P}<0.05)$ than the constant -0.2 $\mathrm{MPa}$ water potential by non-overlap of confidence intervals.

(Table 2). One day of soil moisture availability is not uncommon in southeastern Arizona. Analysis of rainfall data from there has shown that $45 \%$ of the precipitation events are $<2.5 \mathrm{~mm}$ (Frasier and Lopez 1990). The dramatic decrease in germination after dehydration as the length of imbibition time increased, indicates that greater than 1 day of imbibition will result in significant losses of germinating seeds if subsequent moisture requirements for seedling establishment are not met.

The imbibition, and full and partial dehydration sequences used in this experiment are similar to seed hardening and priming treatments that have been used to enhance germination rate for many agricultural species (Heydecker and Coolbear 1977) and some range grasses (Hardegree 1994, Beckman et al. 1993, Haferkamp et al. 1977b, Bleak and Keller 1974). Improved germination from seed hydration treatments has been attributed to metabolic repair (Burgass and Powell 1984, Osborne 1983), synthesis of germination metabolites (Mazor et al. 1984), and reduced imbibition time. Germination enhancement from hydration and dehydration sequences in a field setting may provide an establishment advantage to some seeds by increasing germination rate. This experiment indicates that the advantage would be small for these species at the tested temperature. Germination rate enhancement was up to 1 day and confined to partial dehydration seed priming treatments (Table 3). Low temperature germination rate of some cool season grasses have been increased by as much as 4-8 days by seed priming treatments (Hardegree 1994). The small increase in germination rate of the partially dehydrated seeds in this experiment may have been caused by simple reduction in the lag time for imbibition relative to the controls. Also the increase in germination rates would probably not overcome the losses in seed viability in the overall process of seedling establishment. 


\section{Literature Cited}

Beckman, J.J., L.E. Moser, K. Kubik, and S.S. Waller. 1993. Big bluestem and switchgrass establishment as influenced by seed priming. Agron. J. 85:199-202.

Bleak, A.T. and W. Keller. 1974. Emergence and yield of six range grasses planted on four dates using natural and treated seed. J. Range Manage. 27:225-227.

Burgass, R.W. and A.A. Powell. 1984. Evidence for repair processes in the invigoration of seeds by hydration. Ann. Bot. 53:753-757.

Cox, J.R. and G.L. Jordan. 1983. Density and production of seeded range grasses in southeastern Arizona (1970-1982). J. Range Manage. 36:649-652.

Cox, J.R., M.H. Martin-R, F.A. Ibarra-A, J.H. Fourie, N.F.G. Rethman, and D.G. Wilcox. 1987. Effects of climate and soils on the distribution of four african grasses, p. 225-241. In: G.W. Frasier and R.A. Evans (ed.) Seed and seedbed ecology of rangeland plants. Proc. of Symp. Tucson, Ariz. 21-23 Apr. 1987. USDA-ARS.

Emmerich, W.E. and S.P. Hardegree. 1990. Polyethylene glycol solution contact effects on seed germination. Agron. J. 82:1103-1107.

Emmerich, W.E. and S.P. Hardegree. 1991. Seed germination in polyethylene glycol solution: Effects of filter paper exclusion and water vapor loss. Crop Sci. 31:454-458.

Frasier, G.W. and F. Lopez. 1990. Optimizing wet-dry precipitation probabilities for improved plant establishment, p.395-404. In: Proc. ASCE Conf., Watershed Planning and Analysis in Action, Committee on Watershed Management and Irrigation and Drain, Div., Durango, Colo., July 9-11, 1990.

Frasier, G.W., J.R. Cox, and D.A. Woolhiser. 1985. Emergence and survival response of seven grasses for six wet-dry sequences. J. Range Manage. 38:372-377.

Frasier, G.W., D.A. Woolhiser, and J.R. Cox. 1984. Emergence and seedling survival of two warm-season grasses as influenced by the timing of precipitation: A greenhouse study. J. Range Manage. 37:7-11.

Haferkamp, M.R., G.L. Jordan, and K. Matsuda. 1977a. Physiological development of Lehmann lovegrass seeds during the initial hours of imbibition. Agron. J. 69:295-299.

Haferkamp, M.R., G.L. Jordan, and K. Matsuda. 1977b. Pre-sowing seed treatments, seed coats, and metabolic activity of Lehmann lovegrass seeds. Agron. J. 69:527-530.

Hardegree, S.P. 1994. Matric priming increases germination rate of great basin native perennial grasses. Agron. J. 86:289-293.

Hardegree, S.P. and W.E. Emmerich. 1990a. Partitioning water potential and specific salt effects on seed germination of four grasses. Ann. Bot. 66:587-595.

Hardegree, S.P. and W.E. Emmerich. 1990b. Effect of polyethylene glycol exclusion on the water potential of solution-saturated filter paper. Plant Physiol. 92:462-466.

Hardegree, S.P. and W.E. Emmerich. 1991. Variability in germination rate among seed lots of Lehmann lovegrass. J. Range Manage. 44:323-326.

Hardegree, S.P. and W.E. Emmerich. 1992a. Effect of matric-priming duration and priming water potential on germination of four grasses. $J$. Expt. Bot. 43:233-238.

Hardegree, S.P. and W.E. Emmerich. 1992b. Seed germination response of four southwestern range grasses to equilibration at subgermination matric-potentials. Agron. J. 84:994-998.

Hardegree, S.P. and W.E. Emmerich. 1994. Seed germination response to polyethylene solution depth. Seed Sci. \& Tech. 22:1-7.

Hegarty, T.W. 1978. The physiology of seed hydration and dehydration, and the relation between water stress and the control of germination: A review. Plant Cell Environ. 1:101-119.

Heydecker, W. and P. Coolbear. 1977. Seed treatments for improved performance-survey and attempted prognosis. Seed Sci. Tech. $5: 353-425$.

Lalonde, L. and J.D. Bewley. 1985. Desiccation of imbibed and germinating pea axes causes a partial reversal of germination events. Can. J. Bot. 63:2248-2253.

Mazor, L., M. Perl, and M. Negbi. 1984. Changes in some ATP-dependent activities in seeds during treatment with polyethyleneglycol and during the redrying process. J. Expt. Bot. 35:1119-1127.
Osborn, H.B. 1968. Persistence of summer rainy and drought periods on a semiarid rangeland watershed. Bull. IASH, 13:14-19.

Osborne, D.J. 1983. Biochemical control systems operating in the early hours of germination. Can. J. Bot. 61:3568-3577.

Roundy, B.A., V.K. Winkel, J.R. Cox, A.K. Dobrenz, and H. Tewolde. 1993. Sowing depth and soil water effects on seedling emergence and root morphology of three warm-season grasses. Agron. J. 85:975-982.

Simanton, J.R. and G.L. Jordan. 1986. Early root and shoot elongation of selected warm-season perennial grasses. J. Range Manage. 39:63-67.

Watt, L.A. 1982. Germination characteristics of several grass species affected by limiting water potentials imposed through a cracking black clay soil. Aust. J. Agr. Res. 33:223-231.

Wester, D.B. 1991. A summary of range plant seed germination research. ICASALS Pub. no. 91-2.

Wilson, A.M. 1973. Responses of crested wheatgrass seeds to environment. J. Range Manage. 26:43-46.

Wright, L.N. 1973. Seed dormancy, germination environment, and seed structure of Lehmann lovegrass, Eragrostis lehmanniana Nees. Crop Sci. $13: 432-435$. 